\title{
Sin fines de lucro. Por qué la democracia necesita de las humanidades
}

\author{
Dra. Lucía Villamizar Herrera* \\ Fundación Universitaria Católica Lumen Gentium, Cali, Colombia
}

* Adaptada de

Nussbaum, M.C. (2010).

Sin fines de lucro. Por qué

la democracia necesita de los

humanistas. Traducción de

María Victoria Rodil

Katz (Eds). Madrid, España. 199p.
En tanto las humanidades parecen desfigurarse al ritmo de la creciente crisis de la humanidad, Martha Nussbaum, conocida pensadora norteamericana, se aproxima valientemente a la discusión, por cierto ya un tanto vieja sobre si la educación debe buscar la formación de las capacidades humanas tuteladas por el espíritu, o si por el contrario, bajo el susurro de la globalización capitalista debe ceñirse exclusivamente a preparar en competencias instrumentales para el desarrollo de la economía de mercado. En otras palabras, es necesario hoy más que nunca volver a establecer un proyecto educativo, cuya fuente esencial sean las artes liberales como camino para pensar la racionalidad tecnológica y no lo contrario, como parece estar sucediendo.

Vivimos un mundo cuya finalidad no es otra que capacitar para competir siempre por un fin económico, en eso consiste el ideal de la época, pero en el libro Sin fines de lucro. Por qué la democracia necesita de las humanidades, Nussbaum devela la urgencia de volver a pensar la educación como formación o cultivo del intelecto y de las sensibilidades éticas, estéticas espirituales, bajo las cuales el ideal de civilización occidental pudo, durante un tiempo de la historia, sostener y cultivar sociedades democráticas e ilustradas.

La democracia por su propia dinámica, tendiente a la igualdad, será siempre una búsqueda de equilibrio en el reparto de las riquezas, no solo económicas, sino también culturales; sin embargo, la gran pasión de la racionalidad instrumental por el progreso en términos de prosperidad notoria, fue socavando poco a poco el valor educativo de las humanidades hasta casi convertirlas en una figura simbólica, una especie de memoria pasada que perteneció a otro momento, y que necesita ser remplazada por la economía lucrativa en detrimento del ser propio de lo humano. 
Para volver a valorar las humanidades, es necesario poner la tonalidad del pensamiento a favor de la democracia, entendida esta como la búsqueda permanente de la superación de las desigualdades sociales sobre las cuales se tejió el inconsciente del capitalismo, tal como hoy lo conocemos.

No puede haber democracia sin una educación que vuelva a ocuparse de pensar el desarrollo humano, en términos de igualdad de oportunidades y de diálogo alrededor de las profundas diferencias que la riqueza de unos pocos proyecta como pobreza en las grandes mayorías.

Las humanidades son, quizá, el eslabón perdido de unas sociedades que buscan desesperadamente poner al hombre al servicio de la riqueza y las tecnologías, como el centro de todo avance en materia de consumo, dejando un lugar privilegiado al acaparamiento y la desigualdad; creando a la final con todo esto, un mundo en el que fácilmente podremos encontrar más basura y desechos que seres humanos. Por eso, una buena democracia solo puede fecundarse al amparo de las humanidades, promoviendo la razón y la educación de las emociones, como el camino para refundar la democracia y hacerla viable a nivel mundial, como tarea crítica de la globalización mercantil.
La tecnología como instrumentalización del mundo termina reducida a una moneda de cambio que se pone a favor de las pocas grandes multinacionales que hoy gobiernan el mundo, nutriendo en ellas la deshumanización de sus fines y reduciendo a la propia racionalidad tecnológica a un instrumento de poder político y financiero, olvidando que, a pesar del devenir objetivante del mundo, el ser humano sigue estando allí en el centro de la vida y en el futuro de nuestra especie.

Vale pues la pena, tener en cuenta libros como en de Martha Nussbaum, cuya importancia radica en volver a preguntarnos por el sentido de la vida humana y no por el precio de los individuos desbordados por el universo mercantil. La pregunta por la democracia es, también, el interrogante acerca de qué tipo de formación queremos ofrecer a las generaciones del siglo XXI de modo que lo propiamente humano no quede borrado por completo desde la instrumentalización y el olvido de aquello que, en su momento nos hacía comportarnos como seres solidarios respetuosos y cómplices, logrando con ello, recuperar nuestra capacidad de federarnos o de asociarnos en comunidades con vocación de servicio para y por los grupos, en vez de el "sálvese quien pueda", de los actuales individualismos. 